\title{
An obstacle to overcome: cerebral toxoplasmosis in patients living with HIV
}

\author{
Irina Filipescu ${ }^{1 *}$, Roxana lubu², Cristian Marcu², Violeta Năstase², Mirela Flonta², Ligia Ursu², Corina Itu² \\ From The 7th Romanian National HIV/AIDS Congress and The 2nd Central European HIV Forum \\ Sibiu, Romania. 29-31 May 2014
}

Toxoplasmosis represents the most frequent complication affecting the CNS of AIDS patients.

In Europe and South America the prevalence of toxoplasmosis is higher than in the United States (50-75\% to $15 \%)$, so the risk for the AIDS-associated toxoplasmosis is higher in this area, including Romania.

Most of the AIDS patients have immunoglobulin G antibodies anti-Toxoplasma in their serum, like in the general population, so most of the cases represent a reactivation of a latent infection.

We present a series of 5 cases with patients, aged between 19-29 years old, who developed cerebral toxoplasmosis.

Three of the patients are multi-experienced, and for two patients the cerebral toxoplasmosis was the defining AIDS infection.

Three patients had a CD4 count under 100 cells/cmm at the moment of their diagnosis, with low adherence for cART and for the prophylaxis with trimethoprimsulfamethoxazole.

All patients but one had detectable HIV viral load.

Two of the patients are positive for B hepatitis, one of them also for hepatitis D.

The clinical manifestations were persistent headache, confusion, lethargy, hemiparesis.

All patients presented high levels for immunoglobulin G anti-Toxoplasma at the moment of the clinical manifestations, one patient presented immunoglobulin $\mathrm{M}$ anti-Toxoplasma.

The MRI examinations revealed characteristic multiple lesions.

The treatment was performed using trimethoprim-sulfamethoxazole for 6 weeks.

${ }^{1}$ Iuliu Hațieganu University of Medicine and Pharmacy, Cluj-Napoca, Romania Full list of author information is available at the end of the article
The evolution of the patients under the treatment was favorable for all the patients, with the remission of the symptoms and without neurological complications; they received trimethoprim-sulfamethoxazole prophylaxis until their CD4 $>200 / \mathrm{cmm}$, for another three months

Although difficult to diagnose, cerebral toxoplasmosis is treatable and curable, despite of all the associated AIDS pathology.

\section{Authors' details}

${ }^{1}$ Iuliu Hațieganu University of Medicine and Pharmacy, Cluj-Napoca,

Romania. ${ }^{2}$ Infectious Diseases Hospital, Cluj Napoca, Romania.

Published: 29 May 2014

doi:10.1186/1471-2334-14-S4-P48

Cite this article as: Filipescu et al:: An obstacle to overcome: cerebral toxoplasmosis in patients living with HIV. BMC Infectious Diseases 201414 (Suppl 4):P48.

\section{Submit your next manuscript to BioMed Central and take full advantage of: \\ - Convenient online submission \\ - Thorough peer review \\ - No space constraints or color figure charges \\ - Immediate publication on acceptance \\ - Inclusion in PubMed, CAS, Scopus and Google Scholar \\ - Research which is freely available for redistribution

